\title{
PROGNOSTIC UTILITY OF NOVEL BIOMARKERS IN AORTIC VALVE STENOSIS
}

\author{
Pēteris Tretjakovs", Juris Hofmanis, Dace Hofmane, Gita Krievinaa, Leons Blumfelds, \\ Vitolds Mackēvičs, Aivars Lejnieks, and Guntis Bahs
}

Faculty of Medicine, Rīga Stradiṇš University, 16 Dzirciema Str., Rīga, LV-1007, LATVIA

\# Corresponding author, peteris.tretjakovs@ rsu.Iv

Contributed by Aivars Lejnieks

The aim of the present study was to evaluate plasma levels of chemerin, myeloperoxidase (MPO), fibroblast growth factor-21 (FGF-21), thioredoxin reductase-1 (TrxR1), and matrix metallopeptidase-9 (MMP-9) in acquired aortic valve (AoV) stenosis patients to determine correlations between the studied cellular factors, and also clarify the predictive values of these factors as biomarkers in AoV stenosis. AoV stenosis patients were classified into three groups: 17 patients with mild AoV stenosis; 19 with moderate and 15 with severe AoV stenosis. Twenty-four subjects without AoV stenosis were selected as a control group. Our findings suggest that AoV stenosis might be associated with increased chemerin, TrxR1, MPO, and FGF-21 levels in plasma. Moreover, these factors and also MMP-9 already reached statistically significantly elevated levels in the early stages of AoV stenosis, but MPO levels were more pronounced in patients with moderate and severe AoV stenosis. Chemerin was correlated with all of the studied cytokines; TrxR1 and MMP-9 were correlated with several other cellular factors. Our findings (by ROC analysis) suggest that MPO and chemerin might serve as specific and sensitive biomarkers for AoV stenosis without grading the severity, but, in relation to mild AoV stenosis, TrxR1, FGF-21, and MMP-9 also reached good or moderate levels as biomarkers. The cellular factors might serve as novel diagnostic and prognostic biomarkers in AoV stenosis patients, while chemerin and MPO may be more powerful.

Key words: aortic valve stenosis, chemerin, myeloperoxidase, fibroblast growth factor-21, thioredoxin reductase-1, matrix metalloproteinase-9.

\section{INTRODUCTION}

Aortic valve $(\mathrm{AoV})$ stenosis is a progressive disease associated with inflammation and calcium deposition on the valve leaflets. Previous studies have suggested that cellular factors are involved in the different pathways that are related to AoV inflammation and adverse remodelling. Studies have shown that the most significant cellular factors involved in AoV pathogenesis are the hepatocyte growth factor, vascular endothelial growth factor $\mathrm{D}$, intercellular adhesion molecule- 1 , tumour necrosis factor- $\beta$, and interleukin- $1 \beta$ (Kim et al., 2018). There are limited data on the role of cellular factors in the progression of AoV stenosis, and therefore our aim was to identify new cellular factors that could serve as significant biomarkers for AoV stenosis.

Chemerin can be involved in vascular disease complications in different ways, such as a growth factor, chemokine and as an adipokine (Kaur et al., 2018). Chemerin, as a growth factor, has an effect on the activity of matrix metalloproteinases (MMPs), in particular MMP-9, thus causing growth and remodelling of blood vessels, as well as endothelial cell proliferation, migration, and angiogenesis (Heymans et al., 2005). Chemerin also promotes the proliferation and migration of vascular smooth muscle cells, which may lead to vascular structural remodelling (Kunimoto et al., 2015). As a chemokine, chemerin promotes macrophage adhesion to vascular cell adhesion molecule-1 and extracellular matrix protein fibronectin. Chemerin also contributes to increased intracellular $\mathrm{Ca}^{2+}$ concentration, activates pathways of nuclear factor-kappa ( $\kappa)$ B and matrix activated protein kinases in monocytes, macrophages, dendritic cells and endothelial cells (Heymans et al., 2005). Many studies have confirmed that chemerin has inflammatory functions, opposite to that of the findings from Yamawaki and colleagues 
(Yamawaki et al., 2015). Recent studies showed that chemerin plays a critical role in the development of cardiovascular diseases, e.g., coronary atherosclerosis (Spiroglou et al., 2010), acute coronary syndrome (Ji et al., 2014), aortic atherosclerosis, and carotid stenosis (Kammerer et al., 2018). Our previous study showed that the chemerin level is increased in patients with AoV stenosis (Lurins et al., 2018).

Chemerin significantly increases the production of reactive oxygen species (ROS) in cells (Kunimoto et al., 2015). Oxidative stress plays an important role in the development of cardiovascular disorders (El Hadri et al., 2012; Chen et al., 2017). Myeloperoxidase (MPO), a leukocyte-derived redox enzyme, catalyses the formation of ROS and is an index of oxidative stress (Couchie et al., 2017). It is interesting that MPO exerts effects that are beyond its oxidative properties, e.g. pro-inflammatory properties (van der Veen et al., 2009; Nussbaum et al., 2013). Several types of tissue injuries and chronic diseases, including cardiovascular diseases, are associated with MPO-derived oxidants (Khan et al., 2018). Recent findings showed that MPO is highly expressed in the AoV of AoV stenosis patients (Wada et al., 2013). Other data suggest that endothelial dysfunction occurs mainly due to increased MPO release (causing inflammation), which has impact primarily on integrity of the valve rather than aortic structure (Ali et al., 2014). The pathobiology of AoV stenosis is complex and involves multiple features (Akahori et al., 2018), but there are very few published data on the role of MPO.

Until recently, the heart was not traditionally considered as a site of fibroblast growth factor-21 (FGF-21) production. FGF-21 is produced by cardiac cells at significant levels and acts as a cardiomyokine on the heart itself (Planavila et al., 2015a; 2015b). FGF-21 has an ability to protect against cardiac hypertrophy and cardiac inflammation (Planavila et al., 2015b). Its concentration was observed to be associated with increased cardiovascular risk and had a prognostic value in cardiovascular outcomes (Lenart-Lipińska et al., 2015). Circulating FGF-21 levels are elevated in coronary heart disease, atherosclerosis (Planavila et al., 2015), myocardial ischemia, cardiac hypertrophy (Cheng et al., 2016) and also, as our study showed, in AoV stenosis (Lurins et al., 2018). Recent findings indicate that FGF-21 exerts cardioprotective effects, e.g., protects against cardiac hypertrophy and cardiac inflammation (Lenart-Lipińska et al., 2015; Planavila et al., 2015). Studies have shown that FGF-21 protects against oxidative stress, including regulation of genes that are involved in antioxidant pathways, thus preventing ROS production in cardiac cells (Planavila et al., 2015a; 2015b).

The thioredoxin system is one of the main regulators for protection against oxidative stress. The system consists of thioredoxin-1, thioredoxin reductase-1 (TrxR1) and NADPH and regulates the protein dithiol/disulphide balance (El Hadri et al., 2012). TrxR1, a selenoenzyme, exerts not only antioxidant, but also anti-inflammatory and antiapoptotic properties (Chen et al., 2017; Couchie et al., 2017).
Previous studies have shown that TrxR1 is pivotal in atherogenesis (Zhang et al., 2018), but there is almost no study of its role in stenosis of the AoV.

AoV diseases are characterised by pathological remodelling of valvular tissue (Fondard et al., 2005). Diseased AoV are characterised by fibrosis and calcification, where fibrosis is an early pathological change and related to AoV interstitial cell proliferation and overproduction of extracellular matrix proteins (Yao et al., 2017). Studies have shown that MMP-9 is a useful diagnostic marker for fibrosis and cardiac events (Münch et al., 2016). The hallmarks of calcific AoV diseases are the changes of the extracellular matrix, which lead to increased leaflet stiffness and obstruction of left ventricular outflow. MMPs participate in numerous extracellular matrix remodelling events, where MMP-9 may play a key role in promotion of the fibrotic and procalcific remodelling of the extracellular matrix (Perrotta et al., 2016).

The aim of the present study was to evaluate the plasma levels of chemerin, MPO, FGF-21, TrxR1 and MMP-9 in acquired AoV stenosis patients and also to determine correlation between the study cellular factors, as well as clarify the predictive values of these factors as biomarkers in AoV stenosis.

\section{MATERIALS AND METHODS}

Study subjects. AoV stenosis patients were classified into three groups according to the severity of the stenosis: 17 patients (mean \pm SD: $71 \pm 6$ years) with mild AoV stenosis; $19(72 \pm 8)$ with moderate and $15(65 \pm 8)$ with severe AoV stenosis according to the Guidelines on the Management of Valvular Heart Disease 2012 of the European Society of Cardiology (Vahanian et al., 2012). Twenty four subjects $(68 \pm 9$ years) without AoV stenosis (echocardiographically approved) were selected as a control group. The study groups were matched by age, sex, and body mass index. Patients who had evidence of bicuspid AoV and congenital or rheumatic AoV stenosis were not included. Taking into account that some the studied cellular factors were adipokines, exclusion criteria were obesity, diabetes mellitus, hypercholesterolemia and hypertriglyceridemia. Other exclusion criteria were smoking, arterial hypertension, coronary artery disease, myocardial or cerebral infarction, peripheral vascular disease, thyroid dysfunction, acute inflammatory condition or chronic inflammatory states such as rheumatoid arthritis, systemic lupus erythematosus, vasculitis, inflammatory bowel disease, renal or liver diseases, or malignancies, and other diseases that are known to be associated with significant changes of cellular factors, including surgery or trauma within the preceding 30 days. We did not include patients who were taking COX-2 inhibitors, nonsteroidal anti-inflammatory agents or corticosteroids, or had been taking them within the preceding 30 days. All patients were included in the study during outpatient examinations. All subjects gave their informed consent to the protocol, which was approved by the local Medical Ethics 
Committee of the Rịga Stradiņš University for biomedical research.

AoV stenosis assessment. Patients were examined echocardiographically, and the data were archived using GE VIVID 7 Dimension and Philips IE 33, both from KPI Healthcare (Yorba Linda, CA, USA). Each echocardiography examination was evaluated by two professionals. Patients with AoV stenosis were subdivided into three groups depending on the severity grade according to the echocardiography criteria: aortic jet velocity $\left(\mathrm{V}_{\max }\right)(\mathrm{m} / \mathrm{sec})$; mean pressure gradient, PG $(\mathrm{mmHg})$; aortic valve area, AVA $\left(\mathrm{cm}^{2}\right)$ and indexed AVA $\left(\mathrm{cm}^{2} / \mathrm{m}^{2}\right)$. Data were graded as: severe: $\mathrm{V}_{\max }>4$ $\mathrm{m} / \mathrm{sec}, \mathrm{PG}>40 \mathrm{mmHg}, \mathrm{AVA}<1.0 \mathrm{~cm}^{2}$, indexed AVA $<$ 0.6; moderate: $\mathrm{V}_{\max } 3.0-4.0 \mathrm{~m} / \mathrm{sec}, \mathrm{PG} 20-40 \mathrm{mmHg}$, AVA 1.0-1.5 $\mathrm{cm}^{2}$, indexed AVA 0.60-0.85; and mild: $\mathrm{V}_{\max }$ 2.5-2.9 m/sec, PG $<20 \mathrm{mmHg}$, AVA $>1.5 \mathrm{~cm}^{2}$, indexed AVA > 0.85 (Vahanian et al., 2012).

Laboratory assays. Venous blood samples of the subjects were collected after overnight fasting, centrifuged, and stored at $-80^{\circ} \mathrm{C}$. Chemerin, MPO, FGF-21, TrxR1, and MMP-9 were measured in plasma by ELISA method using a TECAN Infinite 200 PRO multimode reader (Tecan Group, Ltd., Mannedorf, Switzerland). Concentrations of lipids, glucose, and other routine blood biomarkers were analysed by standard methods.

Statistical analysis. To estimate the data distribution we used the Lilliefors and Shapiro-Wilk's tests. Data were calculated as the medians and interquartile ranges (IQR). Statistical differences between two groups were analysed by the Mann-Whitney test and differences among four subgroups of the study assessed by the Kruskal-Wallis test. A regression analysis was performed to evaluate the relations between the study biomarkers. The performance of the study biomarkers was assessed using receiver-operating characteristic (ROC) curves, sensitivity, specificity, and negative and positive predictive values. The $p$-value was reported for the area under the curve (AUC) for the best cutoff level. Diagnostic tests were assessed by this classification: $0.90-1=$ excellent; $0.80-0.90=$ good; $0.70-0.80=$ fair; $0.60-0.70=$ poor; and $0.50-0.60=$ fail. All analyses were performed using STATISTICA 10 software (StatSoft Inc., USA).

\section{RESULTS}

Patients with AoV stenosis had a significantly higher plasma level of chemerin compared to controls (57.24 (43.84-75.96) vs. 32.24 (31.14-42.18) ng/ml, $p<0.0001)$. Interestingly, the chemerin level was highest in patients with mild and moderate AoV stenosis $(p<0.001)$, but not with severe AoV stenosis $(p<0.05)$ (Table 1).

Also, the level of MPO was significantly higher in patients with AoV stenosis compared to controls (34.94 (28.69-40.50) vs. 27.12 (24.43-30.20) ng/ml, $p<0.0001)$. Regarding MPO, patient subgroups showed slightly different arrangement of levels than in the case of chemerin. Figure 1 shows that the greatest difference of MPO level was in patients with moderate AoV stenosis $(p<0.0001)$, while MPO was statistically significantly higher in patients with severe AoV stenosis $(p<0.05$ and $p<0.001)$ (Table 1$)$.

Although the FGF-21 level was also higher in patients than in the controls, its statistical significance was lower than other cellular factors studied (367.77 (222.08-524.63) vs. 282.99 (132.58-386.43) ng/ml, $p<0.05)$, except MMP-9. The FGF-21 level was significantly different only in patients with mild and severe AoV stenosis $(p<0.05$ and $p<$ 0.05) (Table 1).

A slightly more pronounced difference was observed between TrxR1 levels in patients with AoV stenosis and controls compared to FGF-21 (25.10 (19.13-36.53) vs. 21.34 $(17.48-23.36) \mathrm{ng} / \mathrm{ml}, p<0.01)$. Figure 1 demonstrates that the highest difference of TrxR1 levels is in patients with mild AoV stenosis $(p<0.001)$, but in patients with moderate AoV stenosis TrxR1 did not show significant differences from control subjects, however in patients with severe AoV stenosis TrxR1 levels reached the levels of statistical significance $(p<0.05)$.

The level of MMP-9 did not significantly differ in the patients with AoV stenosis compared to controls (2900 (2367-3593) vs. 2585 (2152-3037) ng/ml, $p<0.05)$, but the MMP-9 level was significantly different in patients with mild and severe AoV stenosis $(p<0.05$ and $p<0.05)$ (Table 1).

BIOMARKERS OF STUDY GROUPS

\begin{tabular}{|c|c|c|c|c|c|}
\hline \multirow[t]{2}{*}{ Biomarker } & \multirow{2}{*}{$\begin{array}{l}\text { Control } \\
\text { group } \\
\mathrm{n}=24\end{array}$} & \multicolumn{3}{|c|}{ AoV stenosis patients group } & \multirow{2}{*}{$p$-value } \\
\hline & & $\begin{array}{l}\text { mild stenosis } \\
\mathrm{n}=17\end{array}$ & $\begin{array}{c}\text { moderate stenosis } \\
\mathrm{n}=19\end{array}$ & $\begin{array}{l}\text { severe stenosis } \\
\mathrm{n}=15\end{array}$ & \\
\hline Chemerin, ng/mg & $32.24(31.14-42.18)$ & $67.97 * *(45.33-83.16)$ & $57.94^{* *}(45.40-76.00)$ & $50.43 *(35.22-64.15)$ & 0.0005 \\
\hline MPO, ng/mg & $27.12(24.43-30.20)$ & $27.86(23.77-40.34)$ & $35.17 * * *(29.88-40.01)$ & $35.77 * *(28.46-46.57)$ & 0.002 \\
\hline FGF-21, pg/ml & $282.99(132.58-386.43)$ & $352.05 *(310.28-492.20)$ & $309.38(184.69-593.18)$ & $439.63 *(287.25-714.51)$ & NS \\
\hline TrxR1, ng/mg & $21.34(17.48-23.36)$ & $27.86 * *(23.77-40.34)$ & 21.07 (16.14- 27.49) & $23.73 *(19.13-33.74)$ & 0.002 \\
\hline MMP-9, pg/ml & $2585.2(2152.4-3037.2)$ & $3248.9 *(2824.0-3686.2)$ & $2547.1(2077.1-2900.0)$ & $2972.4 *(2692.4-3495.3)$ & 0.032 \\
\hline
\end{tabular}

Data are expressed as number (n), or median (IQR); AoV, aortic valve; MPO, myeloperoxidase; FGF, fibroblast growth factor; TrxR, thioredoxin reductase; MMP, matrix metallopeptidase; NS, not significant ( $p>0.05$ compared to all group); $* p<0.05$, ** $p<0.01, * * * p<0.001$ compared to control group. 
CORRELATION OF BIOMARKERS*

\begin{tabular}{lccccc}
\hline & Chemerin & MPO & FGF-21 & TrxR1 & MMP-9 \\
\hline Chemerin & - & & & & \\
MPO & $\mathrm{r}=0.32 ;$ & - & & \\
& $p=0.006$ & & & \\
FGF-21 & $\mathrm{r}=0.41 ;$ & $\mathrm{NS}$ & - & \\
& $p=0.006$ & & & \\
TrxR1 & $\mathrm{r}=0.31 ;$ & $\mathrm{r}=0.30 ;$ & $\mathrm{r}=0.25 ;$ & - & \\
& $p=0.0002$ & $p=0.008$ & $p=0.031$ & & \\
MMP-9 & $\mathrm{r}=0.37 ;$ & $\mathrm{r}=0.37 ;$ & $\mathrm{NS}$ & $\mathrm{NS}$ & \\
& $p=0.001$ & $p=0.001$ & &
\end{tabular}

Abbreviations see in Table 1. * data from all patients and controls; NS. not significant.

We found several correlations between the study cellular factors (Table 2). First of all, we found that chemerin significantly correlated with all other studied cellular factors: MPO $(p=0.006)$, FGF-21 $(p=0.006), \operatorname{TrxR} 1(p=0.0002)$ and MMP-9 $(p=0.001)$. Furthermore we established close correlation between MPO and TrxR1 $(p=0.008)$ as well as between MPO and MMP-9 $(p=0.001)$. We also found significant correlation between FGF-21 and TrxR1 $(p=0.031)$.

To evaluate the predictive values of the study cellular factors as biomarkers in AoV stenosis we used ROC analysis. The analysis showed that chemerin is a moderate (fair) diagnostic marker in all AoV stenosis groups without grading the severity $(\mathrm{AUC}=0.786)$ (Fig. 1 , Table 3$)$. Also, the ROC curve shows that chemerin is a specific and sensitive biomarker for mild AoV stenosis (AUC = 0.799) (Fig. 2, Table 4). However, MPO was a good diagnostic marker in all AoV stenosis groups (AUC $=0.801$ ), and was a moderate diagnostic marker in mild $\mathrm{AoV}$ stenosis group (AUC = 0.723). FGF-21 was a poor diagnostic marker in all AoV

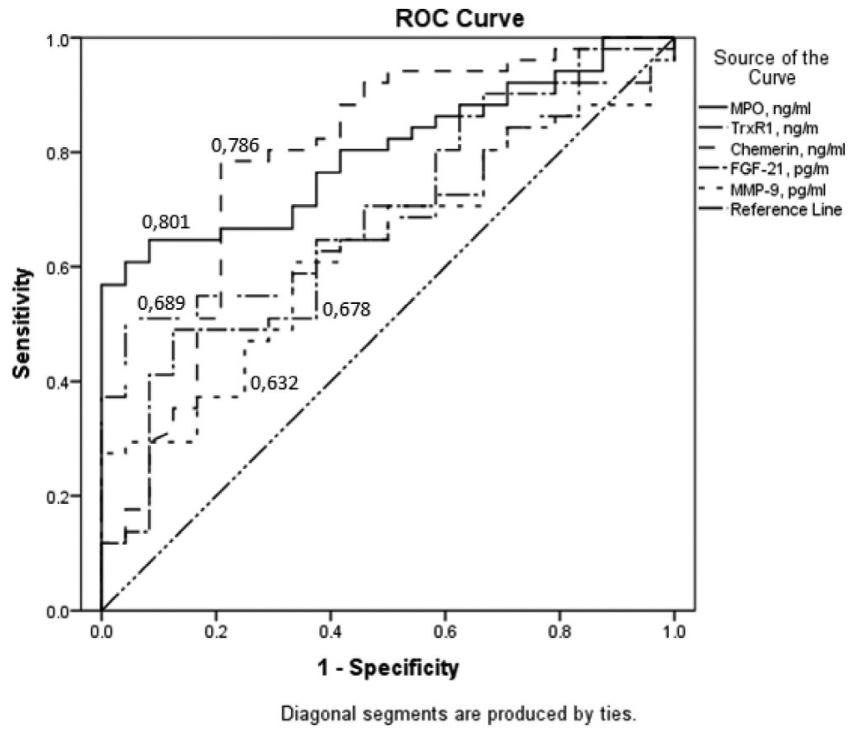

Fig. 1. Receiver-operating characteristic (ROC) curves for chemerin, myeloperoxidase (MPO), fibroblast growth factor-21 (FGF-21), thioredoxin reductase 1 (TrxR1), and matrix metallopeptidase 9 (MMP-9) as diagnostic markers of aortic valve (AoV) stenosis in the control group vs. all stenosis groups.
CHARACTERISTICS OF ROC CURVES AS DIAGNOSTIC MARKERS OF AOV STENOSIS IN THE CONTROL GROUP VS. ALL STENOSIS GROUPS

\begin{tabular}{l|c|c|c}
\hline \multirow{2}{*}{$\begin{array}{c}\text { Test result } \\
\text { variables }\end{array}$} & Area (AUC) & \multicolumn{2}{c}{ Asymptotic 95\% confidence interval } \\
\cline { 3 - 4 } & & lower bound & upper bound \\
\hline MPO, ng/ml & 0.801 & 0.704 & 0.897 \\
TrxR1, ng/m & 0.689 & 0.572 & 0.805 \\
Chemerin, ng/ml & 0.786 & 0.665 & 0.906 \\
FGF-21, pg/m & 0.678 & 0.551 & 0.806 \\
MMP-9, pg/ml & 0.632 & 0.505 & 0.758
\end{tabular}

Abbreviations see in Table 1. AUC, under the curve

Table 4

CHARACTERISTICS OF ROC CURVES AS DIAGNOSTIC MARKERS OF AOV STENOSIS IN THE CONTROL GROUP VS. THE MILD AOV STENOSIS GROUP

\begin{tabular}{l|c|c|c}
\hline \multirow{2}{*}{$\begin{array}{c}\text { Test result } \\
\text { variables }\end{array}$} & Area (AUC) & \multicolumn{2}{|c}{ Asymptotic 95\% confidence interval } \\
\cline { 3 - 4 } & & lower bound & upper bound \\
\hline MPO, ng/ml & 0.723 & 0.556 & 0.890 \\
TrxR1, ng/m & 0.841 & 0.699 & 0.982 \\
Chemerin, ng/ml & 0.799 & 0.655 & 0.943 \\
FGF-21, pg/m & 0.703 & 0.541 & 0.865 \\
MMP-9, pg/ml & 0.733 & 0.561 & 0.905
\end{tabular}

Abbreviations see in Table 1. AUC, under the curve

stenosis groups $(\mathrm{AUC}=0.678)$, although in mild AoV stenosis group it reached moderate level (AUC $=0.703$ ). TrxR1 was also a poor diagnostic marker in all AoV stenosis groups (AUC $=0.689$ ), but showed a good level as a diagnostic marker in the mild AoV stenosis group (AUC = 0.841). Like the previous two cellular factors, MMP-9 was

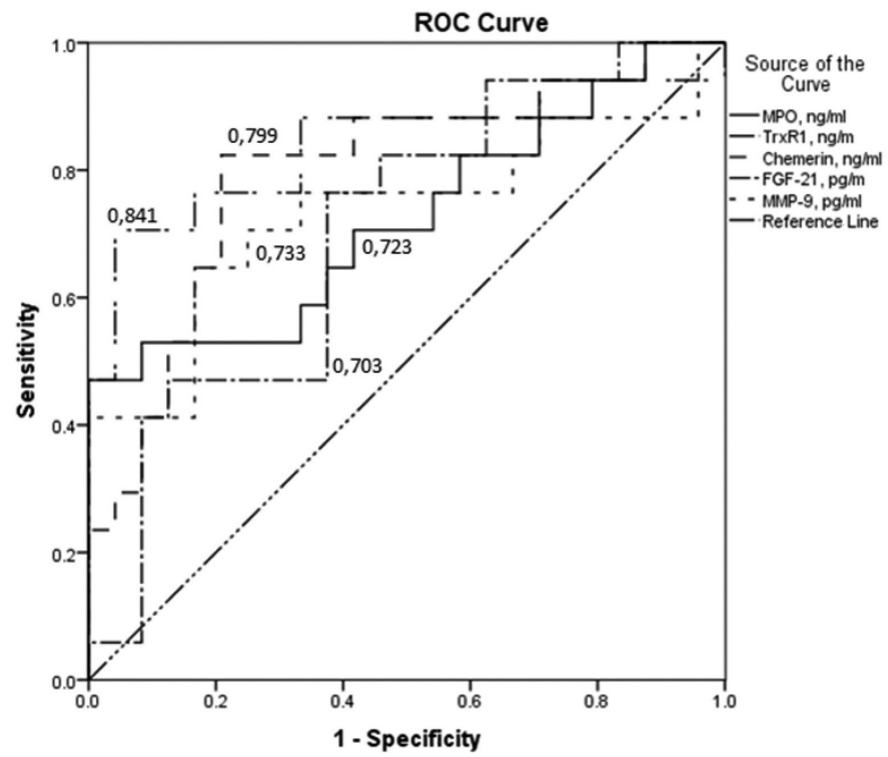

Fig. 2. ROC curves for chemerin, MPO, FGF-21, TrxR1, and MMP-9 as diagnostic markers of AoV stenosis in the control group vs. the mild $\mathrm{AoV}$ stenosis group. Abbreviations see in Fig. 1. 
a poor diagnostic marker in all AoV stenosis groups (AUC $=0.632)$, but it reached a moderate level (AUC $=0.733)$ in the mild AoV stenosis group.

\section{DISSCUSION}

The results showed that patients of our study already had significantly increased levels of all circulating plasma cellular factors (excluding MPO) in the early stage of AoV stenosis, which was most clearly expressed for chemerin and TrxR1. In addition, the closest correlation is between these two factors $(p=0.0002)$. Active inflammation prevails at early stages of AoV stenosis and chemerin plays an important role in endothelial inflammation, including increasing endothelial cell adhesion molecule expression and secretion (El Hadri et al., 2012). Interestingly, TrxR1 levels increase at the same time. It is known that it not only exerts antioxidants, but also anti-inflammatory properties (Chen et al., 2017; Couchie et al., 2017). Moreover, it should be noted that the ROC curve shows that chemerin and TrxR1 are specific and sensitive biomarkers directly for mild AoV stenosis, but they are moderate and poor diagnostic markers in all AoV stenosis groups, without grading the severity. The level of statistical significance of chemerin levels between patients and the control subjects remained in the moderate stage, but a slight decrease was observed in the severe stage of the AoV stenosis patient group. This could be due to the fact that chemerin also acts as a growth factor and has an effect on activity of MMPs (Ali et al., 2014). Levels of TrxR1, which is involved in the system for protection against oxidative stress (El Hadri et al., 2012), lost statistical significance in the moderate stage, but it recovered in the severe stage of AoV stenosis patient group.

MPO, which is as an index of oxidative stress (Couchie et al., 2017), also had pronounced correlation with chemerin $(p=0.006)$ as well as close and positive correlation with TrxR1 in AoV stenosis patients and controls. MPO, unlike TrxR1, reached the highest level in patients with moderate $(p<0.001)$ and maintained high statistical significance in severe AoV stenosis (AoV calcification stage) patients. This AoV calcification is no longer considered as a simple passive process of calcium deposition but as a complex, regulated process that also involves the extent of inflammatory activation and oxidative stress especially in the early stages of AoV stenosis where it first causes endothelial dysfunction and then affects other AoV cells (Akahori et al., 2018). MPO is linked to both inflammation and oxidative stress (Ali et al., 2014). MPO-derived oxidants contribute to tissue damage in many diseases, especially those characterised by inflammation (Nussbaum et al., 2013). MPO, unlike TrxR1 and chemerin, was observed to be a specific and sensitive (good) diagnostic marker in all AoV stenosis groups without grading the severity.

It should be noted that there were many exclusion criteria that are known to be associated with significant changes of cellular factors and oxidative stress biomarkers; to exclude atherosclerosis, the carotid intima-media thickness (Stein $e t$ al., 2008) and ankle-brachial index were evaluated in AoV stenosis patients. Therefore, it was interesting to find an increased level of FGF-21 in the early stage $(p<0.05)$ and also in the severe stage of AoV stenosis patients. Studies have shown that FGF-21 is also produced by the heart and exerts protective effects, and is involved in antioxidant pathways (Planavila et al., 2015; Cheng et al., 2016). FGF-21 was correlated with TrxR1 (an antioxidant biomarker) and chemerin (an inflammatory biomarker) in the patients and controls of our study. FGF-21 was poor as a diagnostic marker in all AoV stenosis groups, but it reached a moderate level in the mild stage of AoV stenosis group patients.

The MMP-9 level was similar to that of FGF-21, increasing in the early stage $(p<0.05)$ and also in the severe stage of AoV stenosis group patients. Considering that MMP-9 is involved in the fibrotic and procalcific remodelling of the extracellular matrix (Münch et al., 2016; Perrotta et al., 2016), an increase in this level is expected in the severe stage, but it is more difficult to explain its increase at an early stage. One explanation might be that increased chemerin stimulates the production of MMP-9 in this stage of AoV stenosis (Kaur et al., 2018). MMP-9 was correlated ( $p=0.001$ ) with chemerin (an inflammatory biomarker) and MPO (an oxidant biomarker) in patients and controls of our study. Similar to FGF-21, MMP-9 is a poor diagnostic marker in all AoV stenosis groups, but it reached moderate levels in the mild stage of AoV stenosis group patients.

The clinical value of individual biomarkers within the single time points is limited. Hence, the future of biomarker application in heart failure, including AoV stenosis, lies in the multimarker panel strategy (Savic-Radojevic et al., 2017). Regarding AoV stenosis, important biomarkers are chemerin, FGF-21 and MMP-9, as well as oxidative stress biomarkers: TrxR1 and MPO.

\section{CONCLUSION}

The findings suggest that AoV stenosis might be associated with increased chemerin, TrxR1, MPO, and FGF-21 levels in plasma (since all subclinical atherosclerotic sites in the body cannot be completely excluded), moreover these cellular factors as well as MMP-9 already reached statistically significant elevated levels at the early stages of AoV stenosis, but MPO levels were more pronounced in patients with moderate and severe AoV stenosis. Chemerin was correlated with all the study cellular factors; TrxR1 and MMP-9 were correlated with several other cellular factors. Our findings (by the ROC analysis) suggest that MPO and chemerin might serve as specific and sensitive biomarkers for AoV stenosis without grading the severity, but in relation to mild AoV stenosis, also TrxR1, FGF-21 and MMP-9 reached good or moderate level as biomarkers. The cellular factors might serve as novel diagnostic and prognostic biomarkers in AoV stenosis patients, but chemerin and MPO may be more powerful. 


\section{ACKNOWLEDGEMENTS}

This study was supported in part by grant No. 2014.10-4/VPP-1.1.2 of the framework of the Latvian National Programme.

The authors declare that there is no conflict of interests regarding the publication of this paper.

\section{REFERENCES}

Akahori, H., Tsujino, T., Masuyama, T., Ishihara, M. (2018). Mechanisms of aortic stenosis. J. Cardiol., 71 (3), 215-220.

Ali, O. A., Chapman, M., Nguyen, T. H., Chirkov, Y. Y., Heresztyn, T., Mundisugih, J., Horowitz, J. D. (2014). Interactions between inflammatory activation and endothelial dysfunction selectively modulate valve disease progression in patients with bicuspid aortic valve. Heart, 100 (10), 800-805.

Chen, B., Meng, L., Shen, T., Gong, H., Qi, R., Zhao, Y., Sun, J., Bao, L., Zhao, G. (2017). Thioredoxin attenuates oxidized low-density lipoprotein induced oxidative stress in human umbilical vein endothelial cells by reducing NADPH oxidase activity. Biochem. Biophys. Res. Commun., 490 (4), 1326-1333.

Cheng, P., Zhang, F., Yu, L., Lin, X., He, L., Li, X., Lu, X., Yan, X., Tan, Y., Zhang, C. (2016). Physiological and pharmacological roles of FGF21 in cardiovascular diseases. J. Diabetes Res., 2016, 1540267.

Couchie, D., Vaisman, B., Abderrazak, A., Mahmood, D. F. D., Hamza, M. M., Canesi, F., Diderot, V., El Hadri, K., Nègre-Salvayre, A., Le Page, A., Fulop, T., Remaley, A. T., Rouis, M. (2017). Human plasma thioredoxin-80 increases with age and in ApoE-/-mice induces inflammation, angiogenesis, and atherosclerosis. Circulation, 136 (5), 464-475.

El Hadri, K., Mahmood, D. F., Couchie, D., Jguirim-Souissi, I., Genze, F., Diderot, V., Syrovets, T., Lunov, O., Simmet, T., Rouis, M. (2012). Thioredoxin-1 promotes anti-inflammatory macrophages of the M2 phenotype and antagonizes atherosclerosis. Arterioscler. Thromb. Vasc. Biol., 32 (6), 1445-1452.

Fondard, O., Detaint, D., Iung, B., Choqueux, C., Adle-Biassette, H., Jarraya, M., Hvass, U., Couetil, J. P., Henin, D., Michel, J. B., Vahanian, A., Jacob, M. P. (2005). Extracellular matrix remodelling in human aortic valve disease: the role of matrix metalloproteinases and their tissue inhibitors. Eur. Heart J., 26 (13), 1333-1341.

Heymans, S., Schroen, B., Vermeersch, P., Milting, H., Gao, F., Kassner, A., Gillijns, H., Herijgers, P., Flameng, W., Carmeliet, P., Van de Werf, F., Pinto, Y. M., Janssens, S. (2005). Increased cardiac expression of tissue inhibitor of metalloproteinase- 1 and tissue inhibitor of metalloproteinase-2 is related to cardiac fibrosis and dysfunction in the chronic pressure-overloaded human heart. Circulation, 112 (8), 1136-1144.

Ji, Q., Lin, Y., Liang, Z., Yu, K., Liu, Y., Fang, Z., Liu, L., Shi, Y., Zeng, Q., Chang, C., Chai, M., Zhou, Y. (2014). Chemerin is a novel biomarker of acute coronary syndrome but not of stable angina pectoris. Cardiovasc. Diabetol., 13, 145.

Kammerer, A., Staab, H., Herberg, M., Kerner, C., Klöting, N., Aust, G. (2018). Increased circulating chemerin in patients with advanced carotid stenosis. BMC Cardiovasc. Disord., 18 (1), 65.

Kaur, J. L., Mattu, H. S., Chatha, K., Randeva, H. S. (2018). Chemerin in human cardiovascular disease. Vascul. Pharmacol., 110, 1-6.

Khan, A. A., Alsahli, M. A., Rahmani, A. H. (2018). Myeloperoxidase as an active disease biomarker: Recent biochemical and pathological perspectives. Med. Sci. (Basel), 6 (2). pii: E33.

Kim, J. B., Kobayashi, Y., Kuznetsova, T., Moneghetti, K. J., Brenner, D. A., O'Malley, R., Dao, C., Wu, J. C., Fischbein, M., Craig Miller, D., Yeung, A. C., Liang, D., Haddad, F., Fearon, W. F. (2018). Int. J. Cardiol., 270, $83-88$.

Received 5 November 2018

Accepted in the final form 3 January 2019
Kunimoto, H., Kazama, K., Takai, M., Oda, M., Okada, M., Yamawaki, H. (2015). Chemerin promotes the proliferation and migration of vascular smooth muscle and increases mouse blood pressure. Amer. J. Physiol. Heart Circ. Physiol., 309 (5), H1017-H1028.

Lenart-Lipińska, M., Duma, D., Hałabiś, M., Dziedzic, M., Solski, J. (2016) Fibroblast growth factor 21 - a key player in cardiovascular disorders? Horm. Mol. Biol. Clin. Investig., 30 (2).

Lurins, J., Lurina, D., Tretjakovs, P., Mackevics,V., Lejnieks, A., Rapisarda, V., Baylon, V. (2018). Increased serum chemerin level to predict early onset of aortic valve stenosis. Biomed. Rep., 8 (1), 31-36.

Münch, J., Avanesov, M., Bannas, P., Säring, D., Krämer, E., Mearini, G., Carrier, L., Suling, A., Lund, G., Patten, M. (2016). Serum matrix metalloproteinases as quantitative biomarkers for myocardial fibrosis and sudden cardiac death risk stratification in patients with hypertrophic cardiomyopathy. J. Card. Fail., 22 (10), 845-850.

Nussbaum, C., Klinke, A., Adam, M., Baldus, S., Sperandio, M. (2013). Myeloperoxidase: A leukocyte-derived protagonist of inflammation and cardiovascular disease. Antioxid. Redox Signal, 18 (6), 692-713.

Perrotta, I., Sciangula, A., Aquila, S., Mazzulla, S. (2016). Matrix metalloproteinase- 9 expression in calcified human aortic valves: A histopathologic, immunohistochemical, and ultrastructural study. Appl. Immunohistochem. Mol. Morphol., 24 (2), 128-137.

Planavila, A., Redondo-Angulo, I., Ribas, F., Garrabou, G., Casademont, J., Giralt, M., Villarroya, F. (2015a). Fibroblast growth factor 21 protects the heart from oxidative stress. Cardiovasc. Res., 106 (1), 19-31.

Planavila, A., Redondo-Angulo, I., Villarroya, F. (2015b). FGF21 and cardiac physiopathology. Front. Endocrinol. (Lausanne), 6, 133.

Savic-Radojevic, A., Pljesa-Ercegovac, M., Matic, M., Simic, D., Radovanovic, S., Simic, T. (2017). Novel biomarkers of heart failure. Adv. Clin. Chem., 79, 93-152.

Spiroglou, S. G., Kostopoulos, C. G., Varakis, J. N., Papadaki, H. H. (2010). Adipokines in periaortic and epicardial adipose tissue: Differential expression and relation to atherosclerosis. J. Atheroscler. Thromb., 17 (2), 115-130.

Stein, J. H, Korcarz, C. E., Hurst, R. T., Lonn, E., Kendall, C. B., Mohler, E. R., Najjar, S. S., Rembold, C. M., Post, W. S.; American Society of Echocardiography Carotid Intima-Media Thickness Task Force (2008) Use of carotid ultrasound to identify subclinical vascular disease and evaluate cardiovascular disease risk: a consensus statement from the American Society of Echocardiography Carotid Intima-Media Thickness Task Force. J. Amer. Soc. Echocardiogr., 21, 93-111.

Vahanian, A., Iung, B. (2012). The new ESC/EACTS guidelines on the management of valvular heart disease. Arch. Cardiovasc. Dis., 105, 465-467.

van der Veen, B. S., de Winther, M. P., Heeringa, P. (2009). Myeloperoxidase: Molecular mechanisms of action and their relevance to human health and disease. Antioxid. Redox Signal, 11 (11), 2899-2937.

Wada, S., Sugioka, K., Naruko, T., Kato, Y., Shibata, T., Inoue, T., Inaba, M., Ohsawa, M., Yoshiyama, M., Ueda, M. (2013). Myeloperoxidase and progression of aortic valve stenosis in patients undergoing hemodialysis. $J$. Heart Valve Dis., 22 (5), 640-647.

Yamawaki, H., Kameshima, S., Usui, T., Okada, M., Hara. Y. (2012). A novel adipocytokine, chemerin exerts anti-inflammatory roles in human vascular endothelial cells. Biochem. Biophys. Res. Commun., 423 (1), 152-157.

Yao, Q., Song, R., Ao, L., Cleveland, J. C Jr., Fullerton, D. A., Meng, X. (2017). Neurotrophin 3 upregulates proliferation and collagen production in human aortic valve interstitial cells: a potential role in aortic valve sclerosis. Amer. J. Physiol. Cell Physiol., 312 (6), C697-C706.

Zhang, H., Liu, Q., Lin, J. L., Wang, Y., Zhang, R. X., Hou, J. B., Yu, B. (2018). Recombinant human thioredoxin-1 protects macrophages from oxidized low-density lipoprotein-induced foam cell formation and cell apoptosis. Biomol. Ther. (Seoul), 26 (2), 121-129. 


\section{JAUNO AORTAS VĀRSTUL̨A STENOZES BIOMARĶIERU PROGNOSTISKĀ VĒRTĪBA}

Pētījuma mērkis bija novērtēt plazmas hemerīna, mieloperoksidāzes (MPO), fibroblastu augšanas faktora-21 (FGF-21), tioredoksīna reduktāzes-1 (TrxR1) un matriksa metaloproteināzes-9 (MMP-9) koncentrācijas iegūtās aortas vārstuḷa (AoV) stenozes pacientiem, lai novērtētu korelācijas starp pētījumā minētajiem pētījuma rādītājiem un noskaidrotu šo rādītāju kā biomarḳieru prognostisko vērtību. Tika izveidotas trīs AoV pacientu grupas: 17 pacienti ar vieglu AoV, 19 ar vidēju un 15 ar smagu AoV, bet 24 indivīdi veidoja kontroles grupu. Iegūtie rezultāti liecina, ka AoV stenoze ir saistīta ar hemerīna, TrxR1, MPO un FGF-21 koncentrācijas palielinājumu, turklāt sasniedzot šo rādītāju un arī MMP-9 koncentrācijas palielinājuma statistisko ticamību pret kontroles grupu jau vieglas AoV stenozes stadijā, bet MPO koncentrācijas palielinājums visvairāk bija izteikts pacientiem ar vidēju un smagu AoV stenozi. Hemerīns korelēja ar visiem pētījuma rādītājiem, savukārt, TrxR1 un MMP-9 arī korelēja ar atsevišķiem rādītājiem. ROC (Receiver Operating Characteristic) līkṇu analīze apliecināja, ka MPO un hemerīns var kalpot kā specifisks un jutīgs biomarķieris AoV stenozei neatkarīgi no AoV stadijas, bet, attiecībā uz pacientiem ar vieglu AoV stadiju arī TrxR1, FGF-21 un MPO sevi apliecināja kā labas un vidējas pakāpes biomarķieri. Visi pētījuma rādītāji var tikt izmantoti kā jauni diagnostiski un prognostiski biomarkieri pacientiem ar AoV stenozi, bet hemerīnam un MPO ir lielāka prognostisko vērtība. 